\section{The Efficacy of Prophylactic Intravenous Granisetron in Preventing Post Anaesthesia Shivering in Gynaecological Patients Undergoing Surgery Under General Anaesthesia}

\author{
ADANIA A, JOANNA OOI SM \\ Department of Anaesthesiology and Intensive Care, Faculty of Medicine, Universiti \\ Kebangsaan Malaysia Medical Centre, Jalan Yaacob Latif, Bandar Tun Razak, 56000 \\ Cheras, Kuala Lumpur, Malaysia
}

\begin{abstract}
ABSTRAK
Menggigil selepas bius umum merupakan salah satu komplikasi yang paling kerap berlaku sewaktu pesakit sedar daripada pembiusan umum dengan kadar di antara 5 hingga 65\%. Keadaan ini meningkatkan penggunaan oksigen dan penghasilan karbon dioksida yang akan menyebabkan kelewatan dari segi pemulihan daripada pembiusan serta kejadian lain yang tidak diingini. Granisetron merupakan salah satu jenis ubat yang digunakan untuk mencegah keadaan menggigil selepas bius umum. Kajian prospektif, sulit berganda dan secara rawak dijalankan untuk membandingkan keberkesanan ubat IV granisetron sebagai profilaksis untuk mencegah keadaan menggigil selepas pembiusan dalam dos $2 \mathrm{mg}$ dan $3 \mathrm{mg}$. Seramai 104 orang pesakit yang terdiri daripada ASA I dan II yang dijadualkan untuk pembedahan elektif ginekologi telah dibahagikan secara rawak kepada dua kumpulan iaitu Kumpulan A dan Kumpulan B yang masing-masing menerima 2 dan $3 \mathrm{mg}$ IV granisetron. Semua pesakit telah dibius dan intubasi trakea dilakukan selepas kelumpuhan otot. Bacaan suhu pesakit dasar dan berkala diukur secara perioperatif. Insiden dan keparahan menggigil selepas pembedahan telah dinilai dengan Klasifikasi 'Wrench Scoring'. Seramai $8.3 \%$ dan 16.7\% pesakit daripada Kumpulan $A$ dan $B$ masing-masing mengalami keadaan menggigil dengan perbezaan yang tidak ketara $(p=0.199)$. Kesemua pesakit yang menggigil daripada kedua-dua kumpulan mengalami tahap menggigil Gred 1 kecuali seorang pesakit dari Kumpulan B mengalami Gred 2. Tiada pesakit mengalami tahap menggigil Gred 3 atau 4 selepas pembedahan atau mengadu loya atau muntah ketika di tempat pemulihan. Kedua-dua dos IV granisetron adalah berkesan untuk mengurangkan insiden dan keparahan menggigil selepas pembedahan ginekologi
\end{abstract}

Address for correspondence and reprint requests: Professor Dr. Joanna Ooi Su Min. Department of Anaesthesiology and Intensive Care, Faculty of Medicine, Universiti Kebangsaan Malaysia Medical Centre, Jalan Yaacob Latif, Bandar Tun Razak, 56000 Cheras, Kuala Lumpur, Malaysia. Tel: +603-91455872 Email: joanna@ppukm.ukm.edu.my 
dengan pembiusan am tanpa kesan sampingan yang kurang menyenangkan.

Kata kunci: bius umum, granisetron, menggigil, pembedahan

\begin{abstract}
Post-anaesthetic shivering is one of the commonest complications during emergence from general anaesthesia with the rate of occurrence between 5 to $65 \%$. It increases oxygen consumption and carbon dioxide production resulting in delayed recovery from anaesthesia and other adverse events. Granisetron is one of the drugs used to prevent post-anaesthetic shivering. This prospective, double-blind and randomised control study compared the efficacy of prophylaxis IV granisetron at $2 \mathrm{mg}$ and $3 \mathrm{mg}$ doses in preventing post-anaesthetic shivering. There were 104 patients, ASA I and II scheduled for elective open gynaecological surgery recruited and randomised into 2 groups: Group A and B, receiving 2 and $3 \mathrm{mg}$ of IV granisetron, resepectively. Intravenous anaesthetic drugs were administered and tracheal intubation was facilitated by muscle paralysis. Patients' baseline and periodic tympanic core temperatures were measured perioperatively. The incidence and severity of shivering were assessed postoperatively using Wrench Scoring Classification whereby Group A and B had 8.3\% and 16.7\% of incidence, respectively, in which they were not statistically significant $(p=0.199)$. All patients from both groups who shivered experienced Grade 1 shivering except for one patient who registered a Grade 2 in Group B. None of our patients had Grade 3 or 4 shivering postoperatively. No one experienced nausea or vomiting in the recovery area. Prophylactic IV granisetron of $2 \mathrm{mg}$ and $3 \mathrm{mg}$ were equally effective in reducing the incidence and severity of post-anaesthetic shivering in gynaecological patients undergoing surgery under general anaesthesia with no unpleasant side effects.
\end{abstract}

Keywords: granisetron, general anaesthesia, shivering, surgery

\section{INTRODUCTION}

Shivering is defined as an involuntary and oscillatory muscular activity that increases the metabolic rate to maintain normal body temperature. It is an unpleasant feeling, which may cause uneasiness and discomfort to patients recovering from general anaesthesia. Post-anaesthetic shivering is one of the commonest complications during emergence from anaesthesia with a rate of occurrence between $5-65 \%$ and is usually preceded by perioperative core hypothermia and vasoconstriction (Buggy \& Crossley 2000; Miller et al. 2009). General anaesthesia impairs the central thermoregulation which results in perioperative hypothermia. It widens the inter-threshold range 
by $\pm 4^{\circ} \mathrm{C}$, whereby the autoregulation of core temperature is not triggered resulting in patients developing intraoperative hypothermia. This is further compounded by the effects from the anaesthetic drugs used that cause peripheral vasodilation which redistributes body heat from the central to the peripheries. Other methods of heat loss include exposure to the cold environment in the operating theatre (OT), heat loss via radiation and convection, insensible evaporative loss from exposure of visceral organs during surgery, intraoperative blood loss and prolonged surgical duration which contributes to perioperative hypothermia (Bhattacharya et al. 2003; Miller et al. 2009).

Post-anaesthetic shivering increases double or even triple oxygen consumption and carbon dioxide production. There will be excessive sympathetic nervous system stimulation which increases metabolic heat production up to $600 \%$ above basal level (De Witte \& Sessler 2002; Bhattacharya et al. 2003; Lopez 2018). High production of carbon dioxide may lead to metabolic acidosis which subsequently causes prolonged drug metabolism, delays recovery from anaesthesia, prolongs coagulation time, decreases clot formation, increases adverse myocardial outcomes and perioperative mortality (Gargari \& Anvari 2017). There is also a risk of delayed wound healing, wound infection and prolonged hospitalisation (Buggy \& Crossley 2000; Miller et al. 2009; Gargari \& Anvari 2017). Postanaesthetic shivering can be prevented by maintaining normothermia during surgery. Non-pharmacological methods in preventing intraoperative hypothermia include the use of forced air-warming devices, radiant heaters, passive insulation using cotton drapes and administration of pre-warmed intravenous fluids. To date, various drugs have been used to prevent or treat post-anaesthetic shivering which include alpha-2 agonists, opioids, tramadol, ketanserin, magnesium sulphate, corticosteroids, doxapram, physostigmine and serotonin antagonist (Buggy \& Crossley 2000; De Witte \& Sessler 2002; Bhattacharya et al. 2003; Golembiewski 2015).

Serotonin (5-hydroxytryptamine), a biological amine, is found in the brain and spinal cord. The balance between norepinephrine and serotonin in the preoptic anteriorhypothalamuscontrols the body temperature set-point in short- and long-term thermoregulation (De Witte \& Sessler 2002). Studies had suggested that serotonergic pathway has a role in the control of postanaesthetic shivering (Sajedi et al. 2008; lqbal et al. 2009; Mahmoud \& Zaki 2013; Gargari \& Anvari 2017). A serotonin receptor antagonist inhibits the reuptake of serotonin at preoptic anterior hypothalamus region. This reduces anaesthetic-induced vasodilatory effects which minimises heat redistribution from core to the peripheries resulting in a reduction in heat loss, thereby maintaining intraoperative normothermia and prevents the occurrence of postanaesthetic shivering (Powell \& Buggy 2000; Mahmoud \& Zaki 2013). Granisetron, a serotonin antagonist, is commonly used as an antiemetic 
drug. It has been demonstrated to be effective in preventing post-anaesthetic shivering without causing respiratory and cardiovascular side effects (Sajedi et al. 2008; Matsota et al. 2019). Both Mahmoud \& Zaki (2013) and lqbal et al. (2009) showed that the administration of either $1 \mathrm{mg}(15 \mathrm{mcg} /$ $\mathrm{kg})$ or $3 \mathrm{mg}(40 \mathrm{mcg} / \mathrm{kg})$ IV granisetron was able to reduce the incidence of post-anaesthetic shivering. However, the number of patients with a shivering score of 3 and 4, which required an intervention and rescue therapy, was significantly higher in patients who received $1 \mathrm{mg}$ granisetron compared to the group that received $3 \mathrm{mg}$ granisetron. We therefore would like to embark on this study to compare the efficacy of prophylactic $2 \mathrm{mg}$ and $3 \mathrm{mg}$ IV granisetron in reducing the incidence and severity of postanaesthetic shivering, nausea and vomiting in gynaecological patients that were under general anaesthesia.

\section{MATERIALS AND METHODS}

\section{Study Design}

This was a prospective, doubleblinded, randomised control study approved by the Research Committee of Department Anaesthesiology \& Intensive Care, Universiti Kebangsaan Malaysia Medical Centre (UKMMC) and the Medical Research and Ethics, UKMMC (Research Code: FF-2017508). A total of 104 patients were recruited with the following inclusion criteria: age between 18-65 years, American Society of Anaesthesiologist (ASA) physical status class I and II and scheduled for elective open gynaecological surgery under general anaesthesia with an estimated duration of surgery between 60-180 minutes. Exclusion criteria included patients with a known history of allergies to test-drug, pre-existing fever, or body mass index (BMI) less than 18 or more than $40 \mathrm{~kg} / \mathrm{m}^{2}$. Patients were randomised into two groups using the computer-generated random numbers and received either $2 \mathrm{mg}$ (Group A) or $3 \mathrm{mg}$ of IV granisetron (Group B).

Preoperative assessment was done on patients the day before their scheduled surgery. The study protocol and methodology were explained to the patients and informed consent taken. Patients were fasted overnight prior to the surgery and given oral midazolam upon call to the OT. All patients received standard monitoring in OT which included non-invasive blood pressure (NIBP), electrocardiography (ECG), pulse oximetry $\left(\mathrm{SpO}_{2}\right)$ and endtidal capnography. A $20 \mathrm{G}$ branula was inserted and connected to a prewarmed maintenance intravenous solution. All patients were covered with a single layer of blanket with convective force air warming blanket which was set at $38^{\circ} \mathrm{C}$.

Once baseline blood pressure, heart rate, pulse oximeter and core tympanic temperature (using Braun Thermo Scan 5 infrared thermometer) were obtained, IV granisetron was administered to the patients. Subsequently, induction of anaesthesia was commenced with preoxygenation followed by administration of intravenous induction drugs. All patients received IV fentanyl $2 \mathrm{mcg} / \mathrm{kg}$, IV propofol 2 
$\mathrm{mg} / \mathrm{kg}$ and IV rocuronium $0.9 \mathrm{mg} / \mathrm{kg}$ were intubated using an appropriate size endotracheal tube. The heat and moisture exchanger (HME) was connected via the breathing circuit to ensure humidification of inspired air. Anaesthesia was maintained by using oxygen-air-sevoflurane regime with $2 \mathrm{~L} / \mathrm{min}$ fresh gas flow to achieve a minimum alveolar concentration (MAC) of 0.9-1.0. IV morphine $0.1 \mathrm{mg} / \mathrm{kg}$ was administered as intraoperative analgesia. All patients in both groups received standard body coverage using surgical drapes during surgery. Intraoperatively, core tympanic temperature was measured and recorded every 30 minutes. The ambient OT temperature and humidity were recorded as well. Patients who required blood transfusion were dropped out from the study. At the end of the surgery, IV atropine and neostigmine were administered to reverse the effect of neuromuscular blockade. Patients were then extubated to a face mask oxygen of $5 \mathrm{~L} / \mathrm{min}$ and sent to the recovery area. All patients were covered with a clean, dry OT gown and a layer of cotton blanket postoperatively.

In the recovery area, besides the standard monitoring of NIBP, ECG and $\mathrm{SpO}_{2}$, the core temperature was measured and recorded every 15 minutes. Shivering severity was assessed and documented according to Wrench Scoring (Table 1) comprising of Grade 0-4 postoperatively by a medical officer who was blinded to this study. Patients with a core temperature of less than $35^{\circ} \mathrm{C}$ or have shivering of Grade 3 or 4 received a forced-air warming blanket that was set at $38^{\circ} \mathrm{C}$. They were further reassessed after 10 minutes, and if the patient was still hypothermic and shivered, IV pethidine $25 \mathrm{mg}$ was administered as a rescue drug.

\section{Statistical Analysis}

The sample size was calculated using the Fisher's exact test from the Power and Sample Size Calculations formula based on the previous studies. A minimum of 94 patients were needed to be recruited to permit type I error of $\alpha$ $=0.05$ and power of $80 \%$. Considering a dropout rate of $10 \%$, the required sample size was 104 patients in total for both groups. Statistical analysis was performed using the SPSS Statistic version 23 (IBM Corp; Armonk, NY, USA). Numerical dependent variables were tested for normality. Parametric data were analysed using independent t-test. The differences in temperature

Table 1: Wrench Scoring on the classification of severity of shivering

\begin{tabular}{cl}
\hline Shivering Grade & Clinical Signs \\
\hline 0 & No shivering \\
1 & Piloerection or peripheral vasoconstriction but no visible shivering \\
2 & Muscular activity in only one muscle group \\
3 & Muscular activity in more than one muscle group but not generalized \\
4 & Generalized shivering involving the whole body \\
\hline
\end{tabular}


from baseline to intraoperative and recovery temperature within each group were analysed using paired t-test. Categorical data were analysed using the Chi-square test. P-value of less than 0.05 was considered as statistically significant.

\section{RESULTS}

A total of 104 patients scheduled for elective open gynaecological surgery were enrolled in this study. Fifty-two patients were randomised to Group A, who received $2 \mathrm{mg}$ IV granisetron and another 52 patients to Group B who received $3 \mathrm{mg}$ of the same drug. However, 8 patients were excluded from analysis (4 from each group) due to high temperature (1 patient) and duration of surgery exceeding 180 minutes (7 patients). The patients' demographics and intraoperative characteristics were comparable except for weight and BMI, which were significantly higher in Group B as shown in Table 2.

Perioperative serial core temperature of patients in both groups is as shown in Figure 1, expressed as mean core temperature $\left({ }^{\circ} \mathrm{C}\right)$. Analysis showed that there was no significant difference in the mean core temperature recorded between the two groups of patient at all specified intervals and all the patients remained normothermic perioperatively with the lowest recorded temperature of $36.3^{\circ} \mathrm{C}$. The graph showed the mean core temperatures for both groups declined drastically from their respective baseline values within the first hour of surgery. Subsequently, the trend remained more consistent throughout the intraoperative period in patients from Group B compared to Group A. Postoperatively, both groups of patients exhibited an increasing trend

Table 2: Demographics and intraoperative characteristics

\begin{tabular}{lccc}
\hline Characteristics & $\begin{array}{c}\text { Group A } \\
(\mathbf{n}=\mathbf{4 8})\end{array}$ & $\begin{array}{c}\text { Group B } \\
(\mathbf{n}=\mathbf{4 8})\end{array}$ & P-value \\
\hline Age (years) & $45.8 \pm 12.9$ & $48.0 \pm 10.7$ & 0.360 \\
Weight $(\mathrm{kg})$ & $62.9 \pm 9.2$ & $68.2 \pm 10.6$ & $0.011^{*}$ \\
Height $(\mathrm{m})$ & $1.56 \pm 0.06$ & $1.57 \pm 0.05$ & 0.646 \\
BMI $\left(\mathrm{kg} . \mathrm{m}^{-2}\right)$ & $25.8 \pm 3.3$ & $27.8 \pm 4.1$ & $0.010^{*}$ \\
Race: & & & \\
Malay & $31(64.6)$ & $33(68.8)$ & 0.886 \\
Chinese & $14(29.2)$ & $13(27.1)$ & \\
Indian & $3(6.2)$ & $2(4.1)$ & \\
Baseline Core temperature $\left({ }^{\circ} \mathrm{C}\right)$ & $36.8 \pm 0.4$ & $36.8 \pm 0.5$ & 0.645 \\
Ambient temperature $\left({ }^{\circ} \mathrm{C}\right)$ & $22.5 \pm 1.1$ & $22.7 \pm 0.9$ & 0.295 \\
OT relative humidity $(\%)$ & $61.0 \pm 3.7$ & $60.4 \pm 3.9$ & 0.457 \\
Duration of surgery $(\mathrm{min})$ & $125.2 \pm 36.8$ & $128.4 \pm 41.3$ & 0.681 \\
\hline
\end{tabular}

Demographics and intra-operative characteristics of patients for both groups. Values expressed as Mean $\pm \mathrm{SD}$ or number $(\%)$ where appropriate. ${ }^{*} \mathrm{P}<0.05$ is statistically significant. Abbreviations: BMI: Body Mass Index; OT: Operating theatre. 


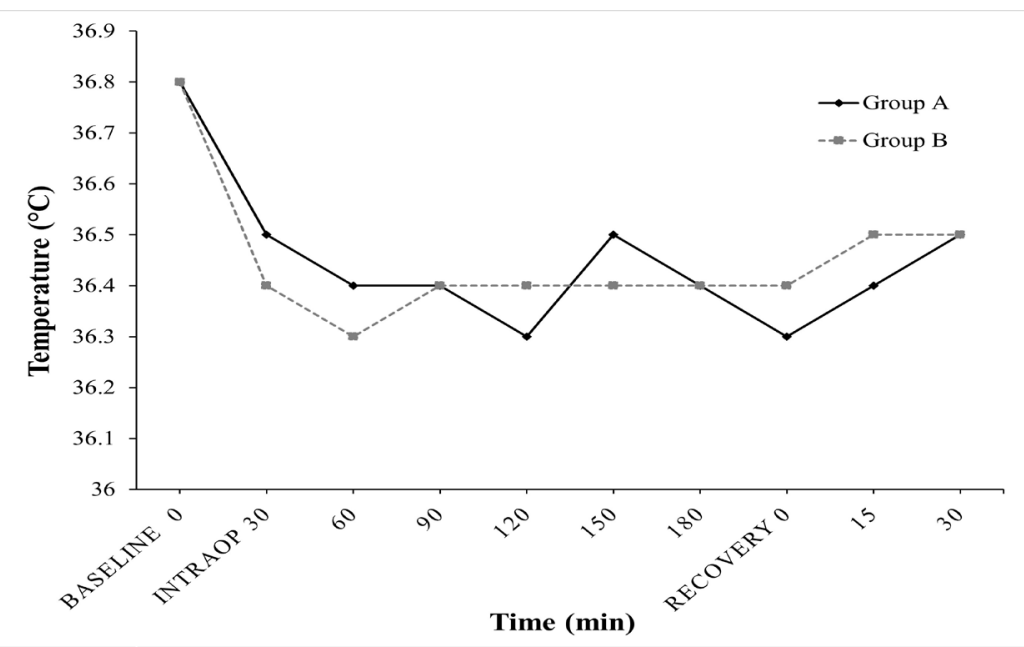

Figure 1: Perioperative mean core temperature. Changes in the mean perioperative core temperature measured periodically. Abbreviations: INTRAOP: intraoperative.

of the core body temperature over a period of 30 minutes while in the recovery area. When comparison was made between the mean core temperature while in the recovery area to its respective baseline values, there was a significant drop in temperature of $0.4^{\circ} \mathrm{C} \quad(p=0.001)$. However, these values were not significantly different when compared between the two groups ( $\mathrm{p}=0.885)$.

The incidence of shivering upon arrival in the recovery area was 8.3\% and $16.7 \%$ in Group $A$ and B, respectively, which was not statistically significant $(p=0.199)$. All patients who shivered had Grade 1 shivering except for one patient who experienced a Grade 2 shivering from Group B. None of our patients had Grade 3 or 4 shivering postoperatively. No one experienced nausea or vomiting in the recovery area. There was no intervention required either using active warming or administration of IV pethidine. None of the patients experienced headache postoperatively as a side effect of a higher dose of IV granisetron. Prior to discharge from the recovery area, all patients were normothermic with a mean temperature of $36.4^{\circ} \mathrm{C}$ and were not shivering.

\section{DISCUSSION}

In this study, we have demonstrated that prophylaxis IV granisetron at both doses of 2 and $3 \mathrm{mg}$ were able to maintain the patients' core body temperature within the normothermic range, with the lowest perioperative temperature of $36.3^{\circ} \mathrm{C}$. This is in accordance with the mechanism of action of granisetron where it reduces the anaesthetic-induced vasodilation that prevents heat redistribution from the core to peripheral. Similar findings were found by lqbal et al. (2009), where the use of $2.6 \mathrm{mg}$ of granisetron (40 $\mathrm{mcg} / \mathrm{kg}$ ) was as effective as $25 \mathrm{mg}$ IV pethidine in preventing the occurrence 
of post-anaesthetic shivering. This further supports the effectiveness of IV granisetron in preventing postanaesthetic shivering.

The first core temperature measured in OT resembled the patient's body temperature in the ward. Subsequently, there was a sharp decline in the mean core temperature within the first hour of surgery. This may be contributed by the effects of cooler ambient OT temperature, the administration of general anaesthetic drugs and infusion of intravenous fluids (Bindu et al. 2017; Riley \& Andrzejowski 2018). The onset of IV granisetron is three minutes, in which it may not taken effect as yet in maintaining the core body temperature even though it was given prior to induction of general anaesthesia. However, the mean core temperature was maintained throughout the rest of the surgery. Even though both doses of IV granisetron were effective in maintaining the core temperature within the normal range and reducing post-anaesthetic shivering, the perioperative core temperature trend in Group B was more constant as compared to Group A, possibly due to the higher dosage of IV granisetron used.

Ambient OT temperature and recovery area temperature also affects the patient's thermoregulation perioperatively. Patidar \& Tiwari (2018) reported an incidence of 53\% while Iqbal et al. (2009) reported a $30 \%$ incidence of post-anaesthetic shivering with a background ambient temperature of $24-25^{\circ} \mathrm{C}$ and $24^{\circ} \mathrm{C}$, respectively. In our hospital setting, the gynaecology ambient OT temperature was set between $22-23^{\circ} \mathrm{C}$, which was lower compared to other studies. Despite this, all our patients were able to maintain their core temperatures within the normal range throughout the surgery till the recovery period. Thus, prophylactic granisetron in both dosages was effective in maintaining the core temperature and preventing hypothermia.

The incidence of shivering in Group $B$ was higher $(N=8)$ as compared to those in Group $\mathrm{A}(\mathrm{N}=4)$. All our patients received granisetron at the same time, which was prior to induction, but the duration of surgery varied between 60 to 180 minutes. In group B, 6 out of those 8 patients had surgery that took longer than 150 minutes which could explain the higher incidence of Grade 1 shivering. Patidar \& Tiwari (2018) demonstrated a lower shivering severity after giving IV granisetron 40 $\mathrm{mcg} / \mathrm{kg}$ at the end of surgery whilst Iqbal et al. showed the opposite results when IV granisetron was administered prior to induction. Both studies had a duration of surgery of 120 to 180 minutes, respectively (lqbal et al. 2009; Patidar \& Tiwari 2018).

Inhalational agent such as isoflurane exhibits a postoperative effect of tonic stiffening pattern of muscular activity that may be more pronounced with an end-tidal concentration of isoflurane of $0.3 \%$ (Bhattacharya et al. 2003). This may be confused with the normal thermoregulatory shivering. There was a $66.7 \%$ incidence of shivering reported after using isoflurane and a $30 \%$ incidence of shivering with sevoflurane (Iqbal et al. 2009; Vasantha et al. 2016). In our study, 
the patients were maintained under general anaesthesia with sevoflurane in a mixture of oxygen and air. Our results showed that the incidence of shivering was $16.7 \%$ amongst those who received 3mg IV granisetron, which was much lower compared to other studies. However, only $8.3 \%$ of patients in Group A who received $2 \mathrm{mg}$ of granisetron shivered.

From our study, none of the patients experienced nausea and vomiting postoperatively, which was not surprising as granisetron itself is also an antiemetic agent. There was no incidence of headache despite a higher dose of IV granisetron (20 and $40 \mathrm{mcg} / \mathrm{kg}$ ) used in this study. Similarly, previous studies did not reveal any side effects such as headache, dizziness or constipation as well when granisetron was used at high doses (Sajedi et al. 2008; lqbal et al. 2009; Mahmoud \& Zaki 2013; Gargari \& Anvari 2017). All patients were not hypothermic and therefore did not require any intervention such as active warming or IV pethidine as a rescue drug in the recovery area. Those patients who shivered did not require any active intervention because the intensity of shivering was mild. They were safely discharged from the OT after 30 minutes with a mean core temperature of $36.4^{\circ} \mathrm{C}$ and shivering score of zero.

The interpretation of our results from this study may be limited because of the small sample size which may be insufficient to observe the low incidence of possible side effects with a larger dose of IV granisetron, such as headache, dizziness and constipation. Our cohort of patients was randomised according to cases on a daily basis. The significant difference in weight and BMI was by chance. During the surgery, we did not standardise the temperature of the surgical irrigation fluids used. The amount of blood loss, volume and temperature of irrigation fluids used intraoperatively were not taken into account in this study as well.

\section{CONCLUSION}

Prophylactic IV granisetron of $2 \mathrm{mg}$ and $3 \mathrm{mg}$ were equally effective in reducing the incidence and severity of post-anaesthetic shivering among gynaecological patients undergoing surgery under general anaesthesia with no untoward side effects.

\section{REFERENCES}

Bhattacharya, P.K., Bhattacharya, L., Jain, R.K., Agarwal, R.C. 2003. Post anaesthesia shivering (PAS): A review. Indian J Anaesth 47(2): 88-93.

Bindu, B., Bindra, A., Rath, G. 2017. Temperature management under general anesthesia: Compulsion or option. J Anaesthesiol Clin Pharmacol 33(3): 306-16.

Buggy, D.J., Crossley, A.W. 2000. Thermoregulation, mild perioperative hypothermia and postanaesthetic shivering. Br J Anaesth 84(5): 615-28.

De Witte, J., Sessler, D. 2002. Perioperative shivering. Physiology and pharmacology. Anesthesiology 96: 467-84.

Gargari, R.M., Anvari, H.M.P. 2017. Effect of Different Doses of Granisetron on Preventing Postoperative Shivering in Patients undergoing Septorhinoplasty under General Anesthesia. Adv Biosci Clin Med 5(2): 21.

Golembiewski, J. 2015. Pharmacological management of perioperative shivering. J Perianesth Nurs 30(4): 357-9.

Iqbal, A., Ahmed, A., Rudra, A., Wankhede, R.G., Sengupta, S., Das, T., Roy, D. 2009. Prophylactic granisetron vs pethidine for the prevention of postoperative shivering: a randomized control trial. Indian J Anaesth 53(3): 330-4.

Lopez, M.B. 2018. Postanaesthetic shivering - from pathophysiology to prevention. Rom J Anaesth 
Intensive Care 25(1): 73-81.

Mahmoud, M.A.E.M., Zaki, A.M. 2013. Granisetron Reduces Shivering after General Anesthesia. Med J Cairo Univ 81(2): 127-131.

Matsota, P.K., Koliantzaki, I.K., Kostopanagiotou G.G. 2019. Pharmacological approach for the prevention of postoperative shivering: A systematic review of prospective randomized controlled trials. Asian J Anesthesio/ 57(3): 6684.

Miller, R.D., Eriksson, L.I., Fleisher, L.A., WienerKronish, J.P., Young, W.L. 2009. Miller's Anesthesia Ed. 7th. 1 \& 2. Philadephia: Churchill Livingstone.

Patidar, S., Tiwari, S. 2018. To Compare the Efficacy of Dexmedetomidine, Granisetron and Tramadol in Prevention of Post-Operative Shivering In Patients Undergoing Surgeries under General Anesthesia. Sch J App Med Sci 6(9): 3374-8.

Powell, R.M., Buggy, D.J. 2000. Ondansetron given before induction of anesthesia reduces shivering after general anesthesia. Anesth Analg 90(6): 1423-7.

Riley, C., Andrzejowski, J. 2018. Inadvertent perioperative hypothermia. BJA Educ 18(8): 227-33.

Sajedi, P., Yaraghi, A., Moseli, H.A. 2008. Efficacy of granisetron in preventing postanesthetic shivering. Acta Anaesthesiol Taiwan 46(4): 16670.

Vasantha, N.K., Madhusudhana, R., Papireddy, S.M., Krishnamurthy, D., Das, P. 2016. Effect of Buprinorphine and Granisetron in Post Anaesthetic Shivering Following General Anaesthesia-A Comparative Study. IOSR Journal of Dental and Medical Sciences 15(11): 44-8.

Received: 21 Jul 2020

Accepted: 19 Feb 2021 